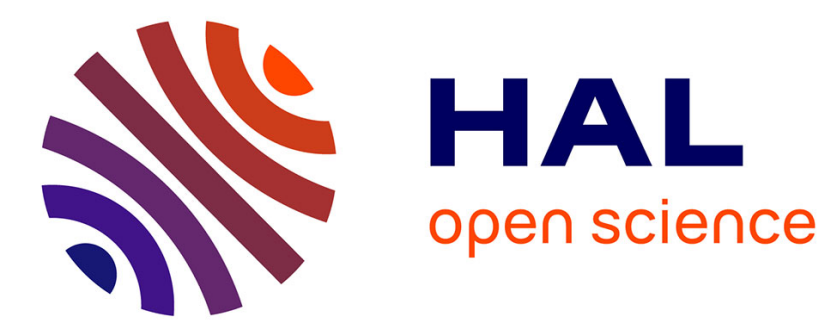

\title{
Comments on the "Spatial variability of coastal surface water temperature during upwelling"
}

\author{
Pierre-Yves Deschamps, Robert Frouin, Lucien Wald
}

\section{To cite this version:}

Pierre-Yves Deschamps, Robert Frouin, Lucien Wald. Comments on the "Spatial variability of coastal surface water temperature during upwelling". Journal of Physical Oceanography, 1980, 10 (8), pp.1303. hal-00464102

HAL Id: hal-00464102

https://hal-mines-paristech.archives-ouvertes.fr/hal-00464102

Submitted on 13 Apr 2010

HAL is a multi-disciplinary open access archive for the deposit and dissemination of scientific research documents, whether they are published or not. The documents may come from teaching and research institutions in France or abroad, or from public or private research centers.
L'archive ouverte pluridisciplinaire HAL, est destinée au dépôt et à la diffusion de documents scientifiques de niveau recherche, publiés ou non, émanant des établissements d'enseignement et de recherche français ou étrangers, des laboratoires publics ou privés. 


\title{
Comments on the "Spatial Variability of Coastal Surface Water Temperature during Upwelling"
}

\author{
P. Y. Deschamps and R. Frouin \\ Laboratoire d'Optique Atmosphérique, ERA 466, Université de Lille I, 59655 Villeneuve D'ASCQ Cedex, France
}

L. WALD

Laboratoire d'Océanographie Physique, Museum National d'Histoire Naturelle, 75231 Paris Cedex 05, France

14 April 1980

In a recent paper, Scarpace and Green (1979) presented a study on the spatial variability of surface water temperature. The temperature density variance $E(k)$ is computed as a function of the wavenumber $k$ from airborne thermal scanner data, and is found to follow a $k^{-p}$ power law with $p=3$ for the wavenumber range from 1 to $25 \mathrm{~km}^{-1}$ (wavelength from 40 to $1000 \mathrm{~m}$ ) and $p=5 / 3$ at wavenumbers $>25 \mathrm{~km}^{-1}$. Nevertheless, these conclusions are rather risky and may be subject to several criticisms.

The first criticism is that the paper refers to twodimensional turbulence theories (Kraichnan, 1967; Charney, 1971) which imply homogeneity and isotropy of the horizontal variability of temperature. This does not apply for the given example of a coastal upwelling for the studied scales. We must also notice that if the velocity spectrum for a homogeneous, isotropic, bidimensional flow predicted by Kraichnan (1967) follows a $k^{-3}$ law, the temperature variance spectrum is a $k^{-1}$ power law (Kraichnan, 1974).

Second, error sources like instrumental noise and cloud cover should have been mentioned and discussed.

Figs. 4-9 of Scarpace and Green (1979) may be understood despite the lack of units. The computed spectra could also be explained by the sums of the actual $k^{-3}$ power laws of the water surface temperature variations and of the $10^{-4}\left({ }^{\circ} \mathrm{C}\right)^{2}$ variance of a typical instrumental noise of an airborne thermal scanner which is assumed to be $0.01^{\circ} \mathrm{C}$. In this case, the observation of $p=5 / 3$ at larger wavenumbers would only be an artifact, and would only mean the joining up of the $k^{-3}$ and the noise spectra A final resolution is possible only if the noise equivalent temperature spectrum of the therma scanner is known.

Because emissivity of water is not exactly 1 , smal variations of a few tenths of $\mathrm{a}^{\circ} \mathrm{C}$ of the observed radiometer temperature may occur, associated with changes in the cloud coverage (Saunders, 1967), sc that the observed density variances could be due at least partially, to other than water surface temperature variations. It may not be the case, bu this point should have been cleared up, either by restricting the flights only to clear-sky conditions or by giving at least a rough estimate of a possible cloud cover effect on the observed density variances.

The conclusions of the paper are not as well es tablished as they could have been. The observec $k^{-3}$ law may be an effect of the cloud cover, and the $5 / 3$ power law may be due to the intrumental noise as well as the actual turbulence spectra of the wate surface temperature.

\section{REFERENCES}

Charney, J. G., 1971: Geostrophic turbulence. J. Atmos. Sci 28, 1087-1095.

Kraichnan, R., 1967: Inertial ranges in two-dimensional turbu lence. Phys. Fluids, 10, 1417-1423.

_ 1974: Convection of a passive scalar by a quasi-unifor random straining field. J. Fluid Mech., 64, 737-762.

Saunders, P. M., 1967: Aerial measurement of sea-surfac temperature in the infra-red. J. Geophys. Res., 72, 4109 4117.

Scarpace, F. L., and T. Green III, 1979: The spatial variability o coastal surface temperature during upwelling. J. Phys Oceanogr., 3, 638-643. 